\title{
Penerapan Permainan Kreatif Mencari Harta Karun Untuk Meningkatkan Kemampuan Memecahkan Masalah Pada Anak Kelompok B Di Taman Kanak-Kanak
}

\author{
Mm. Novita Dwi Setyowati \\ TK Negeri Pembina Kota Kediri \\ mmnovita.dwi@gmail.com
}

\begin{abstract}
Abstrak
Aspek perkembangan kognitif dalam memecahkan masalah adalah aspek utama yang harus dikembangkan dalam masa usia dini, mengingat anak usia dalam mencari pengalaman baru selalu berhubungan dengan kemampuan berpikirnya. Anak belajar melalui kegiatan bermain, melalui penerapan permainan kreatif mencari harta karun dalam pembelajaran dapat meningkatkan kemampuan berpikir dalam memecahkan masalah pada anak, karena permainan ini merupakan permainan penggabungan dari mencari jejak (maze) dan puzzle.Tujuan penelitian Mendeskripsikan penerapan Permainan Kreatif Mencari Harta Karun untuk meningkatkan kemampuan memecahkan masalah pada anak kelompok B di TK Negeri Pembina Kota Kediri. Metode dalam penelitian ini menggunakan: (1) Rancangan penelitian Tindakan kelas, melalui (a) Tahap perencanaan, (b) Tahap pelaksanaan, (c) Observasi kegiatan, (d) Refleksi; (2) Latar dan subjek penelitian anak kelompok B di TK Negeri Pembina Kota Kediri dengan jumlah murid 20 anak; (3) Teknik pengumpulan data dalam penelitian ini adalah dari proses observasi, dokumentasi, tes; (4) Instrumen penelitian menggunakan rancangan kegiatan harian, skenario, media, dan lembar penilaian; (5) Analisis data pada penelitian ini menggunakan rumus hitung rerata (mean) yang mengacu pada keaktifan anak dan keberhasilan anak pada penerapan permainan kreatif mencari harta karun.Hasil dari penelitian penerapan permainan kreatif mencari harta karun untuk meningkatkan kemampuan memecahkan masalah pada anak di TK. Negeri Pembina Kota kediri dilakukan dengan dua siklus dimana setiap siklusnya terdiri dari 2 kali pertemuan. Dari hasil penelitian dapat disimpulkan bahwa penerapan permainan kreatif mencari harta karun dapat meningkatkan kemampuan memecahkan masalah pada anak kelompok B TK Negeri Pembina Kota Kediri.
\end{abstract}

Kata kunci : Permainan Kreatif, Harta Karun, Memecahkan Masalah. 
PENDAHULUAN

Anak usia dini adalah anak pada rentang usia 0-6 tahun, pada usia ini anak memiliki potensi yang besar untuk berkembang sebagai suatu proses perubahan yang berkesinambungan secara progresif dari masa kelahirannya. Pada masa usia dini anak mengalami pertumbuhan dan perkembangan dari segi agama dan moral, motorik (motorik halus dan motorik kasar), kognitif, bahasa, sosial emosional dan juga kepribadiannya ke arah kemandirian dan keingintahuan intelektual yang lebih luas, sehingga anak memiliki keunikan tersendiri sebagai individu dengan pola perkembangannya sendiri. Anak merupakan subyek pembelajar yang aktif, sehingga dalam proses mencari pengalaman secara pribadi mendapat pengalaman fisik dan sosial saat berinteraksi dengan lingkungannya untuk memperoleh hal baru dari apa yang sudah anak kerjakan dalam proses berpikirnya (Ramli, 2005:71).

Anak mencari pengalaman untuk menemukan hal baru, dengan cara menggunakan dan mengembangkan kemampuan berpikir/ kognitif. Kemampuan kognitif adalah kemampuan berpikir, mengingat dan memecahkan masalah. Kemampuan kognitif anak merupakan kemampuan yang mendasar untuk memperoleh pengetahuan dalam mengolah informasi baru melalui proses asimilasi dan mengakomodasi kedalam struktur pengetahuan yang ada yang disebut skema Piaget dalam Ramli (2005 : 91).

Kemampuan berpikir atau kognitif anak sudah mulai terbentuk sejak anak lahir dan berkembang sesuai tingkatan usia, keberhasilan pemahaman anak dalam menerima informasi baru sangat ditentukan dari segi kemampuan berpikirnya. Kemampuan kognitif sangat penting untuk dikembangkan melalui rangsangan pembelajaran yang menarik dan terbaru untuk meningkatkan kinerja otak anak dalam memperoleh pengetahuan dalam proses pembelajarannya.

Pembelajaran anak usia dini hendaknya mengembangkan kecerdasan anak, sehingga perlu disusun dan disesuaikan dengan kebutuhan anak. Adanya penataan lingkungan belajar yang kondusif juga dapat menciptakan suasana psikologis yang nyaman, bebas bergerak, menyenangkan, dan bukan hanya duduk di tempat yang sama sepanjang hari.

Pembelajaran di Taman Kanakkanak, (TK) saat ini dalam penerapannya masih ada sedikit kekurangan dari sistem bermain sambil belajar, pembelajaran banyak dilakukan dengar cara pemberian tugas pada anak, kegiatan pemberian tugas secara terus menerus akan membatasi keaktifan anak dalam belajarnya.

Pembelajaran di TK hendaknya diterapkan dengan sistem bermain sambil belajar, karena dunia anak adalah bermain. Bermain merupakan kegiatan yang dilakukan untuk kesenangan yang ditimbulkannya tanpa mempertimbangkan hasil akhir (Hurlock,1978:320). Kegiatan bermain menurut para ahli memiliki ciri cirri sebagai berikut : (a) bermain selalu menyenangkan dan menikmatkan, (b) bermain tidak bertujuan ekstrinsik, (c) bermain bersifat nonliteral pura pura / tidak senyatanya (Garvey, dalam Musfiroh 2005:6).

Bermain merupakan suatu kegiatan pembelajaran yang sangat penting dalam mengembangkan kemampuan agama dan moral. motorik (motorik halus dan motorik kasar), kognitif, bahasa, sosial emosional dan juga kepribadiannya. Melalui aktivitas bermain itu, anak memiliki kesempatan 
untuk mengembangkan kemampuan memecahkan masalah dalam kegiatan bermain sehingga anak merasa bebas dan dapat belajar secara aktif dalam mengeksplorasi hal baru dengan caranya sendiri. Anak memahami benda atau peristiwa baru berdasarkan teori yang telah dimilikinya untuk membangun dan mengolah teori dengan cara mempraktikan keterampilannya, berdasarkan eksperimen yang dilakukan untuk memperoleh kesimpulan dari pemecahan masalah yang anak hadapi.

Kegiatan mengeksplorasi pengetahuan baru merupakan pemenuhan kebutuhan anak usia dini dalam pembelajaran. Guru perlu melihat tingkat kecerdasan anak dan karakteristiknya, terlebih anak yang belum berkembang kemampuan kognitifnya.

Berdasarkan hasil observasi awal dalam penilaian yang peneliti lakukan terhadap anak kelompok B1 TK Negeri Pembina Kota Kediri, ditemukan beberapa permasalahan yang muncul dalam kegiatan pembelajaran yang berhubungan dengan perkembangan kemampuan kognitif diantaranya kemampuan daya ingat anak, kemampuan konsentrasi anak, kemampuan berpikir dalam memecahkan masalah.

Identifikasi permasalahan yang muncul dalam kegiatan pembelajaran adalah aspek perkembangan kognitif yang berhubungan dengan kemampuan berpikir dalam memecahkan suatu masalah. Berdasarkan analisis dan daya dukung yang ada maka masalah yang segera mendapat solusi adalah aspek perkembangan kognitif yang berhubungan dengan kemampuan berpikir dalam memecahkan suatu masalah. Mengingat kemampuan kognitif merupakan kemampuan berpikir dalam menganalisis kasus dan membantu anak fokus dalam mengerjakan atau melakukan sesuatu, hingga pekerjaan ini dikerjakan dalam waktu tertentu.

Faktor-faktor penyebab munculnya permasalahan perkembangan pada anak usia dini antara lain faktor keturunan yaitu karakteristik yang dibawa sejak lahir dan faktor lingkungan yang berasal dari luar diri anak (Ramli, 2005:80).Menurut Gunarsa (1997:37) faktor keturunan yang berpengaruh terhadap timbulnya sesuatu tingkah laku, dan faktor lingkungan yang mempengaruhi. Guru, orangtua dan teman sebaya merupakan faktor kedua dalam perkembangan anak, pentingnya stimulus dalam kegiatan pembelajaran diharapkan dapat meningkatkan kemampuan kognitif anak.

Berdasarkan penjabaran deskripsi masalah dan faktor yang mempengaruhi perkembangan kognitif anak di atas maka alternatif pemecahan masalah dengan melakukan pendekatan kepada anak dengan cara mencermati aktivitas atau kegiatan yang disukainya, melakukan pendekatan pembelajaran menggunakan kegiatan yang disukai anak, menguatkan perhatian anak secara detail dan terfokus, menguatkan kemampuan berpikir dalam memecahkan masalah dengan cara melakukan permainan kreatif mencari harta karun.

Permainan ini didesain secara khusus untuk melatih kemampuan memecahkan masalah pada anak yaitu dengan menggabungkan permainan maze (mencari jejak) dan menyusun puzzle, dimana anak harus melalui beberapa lintasan dan mengambil kepingan puzzle yang berisi potongan gambar pada setiap pos yang disediakan dan harus disusun kembali sebagai petunjuk untuk menemukan harta karun. 
Berdasarkan beberapa alternatif pemecahan masalah yang telah disebutkan di atas, bisa dipilih satu alternatif pemecahan masalah yaitu; menguatkan kemampuan berpikir dalam memecahkan masalah dengan cara mengerjakan permainan kreatif mencari harta karun, sehingga perlu diadakan penelitian dalam PTK ini yaitu Penerapan Permainan Kreatif Mencari Harta Karun Untuk Meningkatkan Kemampuan Memecahkan Masalah pada Anak Kelompok B1 di TK Negeri Pembina Kota Kediri.

Pembelajaran di TK pada dasarnya dilakukan dengan kegiatan bermain sambil belajar, melalui penerapan permainan kreatif mencari harta karun anak akan belajar berpikir dalam memecahkan masalah pada saat melewati lintasan yang berbeda, serta pada saat menyusun puzzle untuk menemukan harta karunnya, selain itu permainan kreatif mencari harta karun termasuk permainan melatih otak khususnya otak kiri. Anak akin memiliki keteraturan perasaan, ketelitian, memiliki keuletan, berpikir logic, imajinasi dalam mencari dan menemukan harta karunnya, sehingga mampu meningkatkan fungsi kerja otak.

Manfaat permainan mencari harta karun adalah; (1) melatih konsentrasi, ketelitian, dan kesabaran. (2) memperkuat daya ingat. (3) memperkuat konsentrasi. (4) mengenalkan anak pada konsep "hubungan".(5) dengan memilih gambar dapat melatih anak untuk berpikir matematis (menggunakan otak kiri). (6) melatih menyelesaikan masalah (problem solving). online. 26 februari 2017 pk. 20.30 (Definisi Fungsi Edu Toy adekaedutoysandcraft.com).

Penelitian ini secara umum bertujuan untuk perbaikan pembelajaran.
Secara khusus bertujuan Mendeskripsikan penerapan Permainan Kreatif Mencari Harta Karun untuk meningkatkan kemampuan memecahkan masalah pada anak kelompok B I di TK Negeri Pembina Kota Kediri

\section{METODE}

Penelitian ini menggunakan rancangan penelitian tindakan kelas (PTK). PTK adalah penelitian yang bertujuan untuk meningkatkan kualitas proses dan hasil pembelajaran di kelas atau memecahkan masalah pembelajaran di kelas atau di latar yang dilakukan secara bersiklus (Akbar, 2009:28)

Model pelaksanaan PTK ini menggunakan model PTK guru sebagai peneliti dengan acuan model bersiklus PTK yang dikembangkan oleh Kemmis dan Taggrat (1990) Sikhis Model Kurt Lewin ini menjadi acuan pokok para ahli generasi berikutnya, karena Lewin yang pertama mengenalkan PTK.

Model penelitian tindakan yang dikemukakan oleh Lewin terdiri atas: (1) perencanaan (planning), (2) tindakan (acting), (3) observasi (observing), (4) dan refleksi (reflecting) yang membentuk satu siklus langkah berurutan. Kemudian dikembangkan oleh model Kemmis \& MC. Taggart (1990) menjadi lebih dari satu siklus.

Hal yang belum teratasi dalam siklus pertama dilanjutkan dalam siklus kedua, untuk perbaikan pada siklus pertama, karena pada proses implementasi pada siklus pertama dilakukan pengamatan terhadap dampak akibat tindakan, direfleksi dan diambil keputusan untuk perbaikan apa saja dari siklus kedua. (Akbar, 2009:34).

Model pelaksanaan PTK ini menggunakan model PTK "guru menjadi 
peneliti "dengan acuan model siklus PTK yang dikembangkan oleh model Kemmis \& MC. Taggart (1990) dengan digambarkan pada lembar selanjutnya seperti berikut:

\section{SIKLUS PELAKSANAAN PTK}

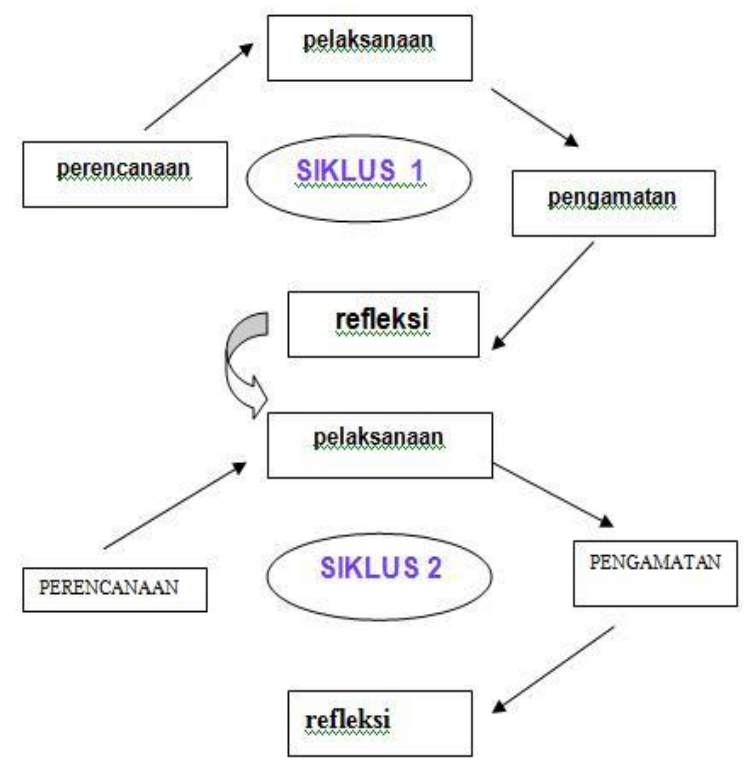

Pada setiap siklus terdiri dari perencanaan, pelaksanaan tindakan, observasi refleksi dan perbaikan. Penelitian tindakan kelas akan berakhir jika permasalahan penelitian sudah terpecahkan dan tujuan penelitian sudah tercapai. Peneliti merencanakan penelitian pada siklus satu sebagai berikut :

\section{SIKLUS I}

Siklus I terdiri atas perencanaan, pelaksanaan tindakan, observasi dan refleksi:

1. Perencanaan : Tahap perencanaan dimulai pada saat penyusunan proposal, peneliti memulai dengan tahapan sebagai berikut:

a. Mengidentifikasi dan menganalisis masalah yang muncul dalam kegiatan pembelajaran yang berhubungan dengan aspek perkembangan kognitif dalam memecahkan masalah pada anak melalui wawancara dengan guru dan observasi pada anak.

b. Menetapkan alasan memilih permasalahan pada aspek perkembangan kognitif dalam memecahkan masalah dan menganalisis faktor-faktor penyebabnya, merumuskan masalah secara jelas, menetapkan alternatif pemecahan masalah yang akan digunakan

c. Memilih pemecahan masalah dengan menjabarkan indikator untuk membuat rancangan tindakan yaitu penyusunan rancangan kegiatan harian, metode, media yang akan digunakan.

d. Membuat instrumen penelitian yaitu lembar observasi kegiatan pembelajaran dan lembar penilaian dari penjabaran indikator yang sudah dipilih.

2. Tindakan : Penerapan rancangan kegiatan harian dan skenario pembelajaran Penerapan Permainan kreatif Mencari Harta Karun Untuk Mengembangkan Kemampuan memecahkan masalah. Tema Rekreasi, sub tema tempat rekreasi dan perlengkapan rekreasi.

3. Pengamatan : Peneliti mengadakan pengamatan pada waktu tindakan berjalan, mencatat permasalahan yang terjadi dalam siklus pertama.

4. Refleksi : Mengkaji menyeluruh hasil dari tindakan yang telah diterapkan, berdasarkan data yang sudah terkumpul. Jika terdapat masalah pada saat refleksi siklus pertama maka dilakukan pengkajian melalui siklus berikutnya atau siklus II. Refleksi dilakukan terus menerus 
selama observasi dan selesainya observasi. Dst.

\section{HASIL DAN PEMBAHASAN}

Berdasarkan data yang telah dipaparkan di atas, maka dapat disimpulkan bahwa dengan menerapkan permainan kreatif mencari harta karun, kemampuan memecahkan masalah pada anak mengalami peningkatan.

Kemampuan memecahkan masalah pada anak meningkat dari siklus I ke siklus II, pada siklus I dengan perolehan persentase nilai $74 \%$, meningkat pada siklus II menjadi $89 \%$. Pada siklus II sudah mengalami peningkatan yaitu $15 \%$. Peningkatan nilai pada siklus I dan siklus II ini dapat dilihat pada tabel dibawah ini:

Tabel 4.1 Peningkatan Nilai Siklus I

Dan II Kemampuan Memecahkan

\begin{tabular}{|l|l|l|}
\multicolumn{3}{c|}{ Masalah } \\
\begin{tabular}{|l|l|l|} 
Persentase & Persentase & Persentase \\
Nilai & Nilai & Hasil \\
Kemampua & Kemampua & Peningkata \\
$\mathrm{n}$ & $\mathrm{n}$ & n Nilai \\
Memecahk & Memecahk & Kemampua \\
an masalah & an masalah & $\mathrm{n}$ \\
Siklus I & Siklus II & Memecahk \\
& & an masalah \\
\hline $\mathbf{7 4 \%}$ & $\mathbf{8 9 \%}$ & $\mathbf{1 5 \%}$ \\
\hline \multicolumn{2}{|c|}{ Persentase nilai } & kemampuan
\end{tabular}
\end{tabular}

memecahkan masalah yang diperoleh anak pada siklus II menjelaskan bahwa terjadi peningkatan hasil belajar. Indikator keberhasilan yang sudah dicapai dan dapat disimpulkan bahwa ketuntasan belajar dalam kemampuan memecahkan masalah meningkat sebesar $15 \%$.

\section{SIMPULAN}

Berdasarkan paparan data hasil penelitian dan pembahasan yang disajikan maka dapat disimpulkan beberapa hal sebagai berikut:

Implementasi Penerapan permainan kreatif mencari harta karun untuk meningkatkan kemampuan memecahkan masalah pada anak kelompok B1 di TK Negeri Pembina Kota Kediri adalah melalui tahap tahap sebagai berikut :

1. Anak dibagi menjadi 3 kelompok, situ kelompok anggotanya 6-7 anak

2. Anak masuk pada pos 1 dengan berjalan melewati garis keseimbangan dan mengambil keping puzzle ke 1

3. Anak masuk pos 2 dengan merangak melewati terowongan dan mengambil keping puzzle ke 2

4. Anak masuk pos 3 dengan engklek mengikuti jejak kaki dan mengambil keping puzzle ke 3

5. Anak masuk pos 4 dengan berlari zigzag melewati rintangan dan mengambil keeping puzzle ke 4

6. Anak menata kepingan puzzle yang diambil dari tiap pos

7. Anak mengambil harta karun dari dalam peti sesuai gambar puzzle yang telah terbentuk.

Pada siklus I hasil pembelajaran anak adalah $74 \%$ dikarenakan tidak adanya petunjuk pada setiap kepingan puzzle membuat anak kesulitan dalam menyusun gambar menjadi bentuk utuh dengan benar, lintasan yang dilalui anak dalam mencari harta karun kurang jelas sehingga anak kesulitan melewati lintasan dg benar.

Pada siklus II hasil pembelajaran anak adalah $89 \%$ dikarenakan pada siklus II ini peneliti memperbaiki media yg digunakan yaitu menyiapkan kepingan puzzle dengan petunjuk angka dan menyiapkan lintasan yang jelas untuk dilalui anak. 
Penerapan permainan kreatif mencari harta karun mampu meningkatkan kemampuan memecahkan masalah pada anak kelompok B1 di Tk Negeri Pembina Kota Kediri dengan peningkatan $15 \%$ dan dinyatakan berhasil untuk menyampaikan tujuan.

\section{DAFTAR RUJUKAN}

Akbar, Sakdun. 2009. Prosedur Penyusunan Laporan dan Artikel Hasil Penelitian Tindakan Kelas, Yogyakarta : Cipta Media Aksara.

Gunarsa, Singgih. 1981. Dasar Dan Teori Perkembangan Anak. Jakarta : PT BPK Gunung Mulia.
Hurlock, Elizabeth. 1978. Perkembangan Anak jilid 1. Jakarta : PT. Gelora Aksara Pratama..

Musfiroh, tadkiroatun. 2005. Bermain Sambil Belajar dan Mengasah Kecerdasan. Jakarta : Depdiknas.

Ramli, Mochamad. 2005. Pendampingan Perkembangan Anak Usia Dini. Jakarta: Depdiknas.

-. 2017. Definisi Fungsi Edu Toy adekaedutoysandcraft.com) diakses Febuari 2017. 